\title{
Evaluation of Bank Products Appeal across Demographic Consideration: A Comparative Study of Nigeria and South Africa
}

\author{
Binuyo, Adekunle Oluwole, Aregbeshola, Rafiu Adewale \\ University of South Africa, Unisa, South Africa \\ binuya@unisa.ac.za
}

\begin{abstract}
Influence of demographic variables on banking has continued to attract the interest of researchers over the years with a good number focussing on impact of demographic variables on choice of banks by customers. This study however differs from previous studies in that its focus is on the evaluation of bank products appeal across demographic variables in South Africa and Nigeria. This descriptive study made use of primary data collected by administering validated and pre-tested questionnaires to 3,684 bank customers within selected strategic locations across Nigeria and South Africa using the snowball sampling technique. Both descriptive and inferential statistics were used to analyse the data generated. High Chi-Square statistics (corroborated with cross - tabulation and correlation analyses) coupled with very low probability values indicate highly significant associations between demographic variables and the dependent variables. The study recommends customer-centric approach on the part of banks to be able to provide customers with effective and unique value offers for various customer segments. Also, policy intervention is required to promote infrastructural upgrade for better product and service delivery. A more inclusive regulatory framework is required to draw more of the unbanked self - employed populace in the interest of boosting the economic performance of both countries.
\end{abstract}

Keywords: Gender, Bank Products Appeal, Evaluation, Demographic Consideration, Nigeria, South Africa

\section{Introduction}

Throughout the past decade structural and regulatory factors have considerably changed the banking environment both in Nigeria and South Africa and have resulted in intensified competition in the market place. The intense competition that exists in the banking industry presents a big challenge to the profitability of retail banking institutions. This is considering the fact that the preferences of the customers of bank products and services is ever dynamic especially as technology advances and diverse innovations have continued to alter the nature of banks' products and services. Recent empirical studies suggest that demographic features wields a significant influence on customers' choice of bank with specific emphasis on such criteria as convenience, customer service, and speed dimensions of bank services (Okoe, Osarenkhoe and Hinson, 2013; Maiyaki, 2011; Rashid and Hassan, 2009; Mokhlis, Salleh, and Mat, 2011). While earlier studies have focussed extensively on influence of customer demographic factors on choice of bank preference, studies investigating customer demographics and bank products nexus have been limited. Hence, this study seeks to contribute to literature by embarking on the empirical investigation of the influence of customer demographic considerations on bank products preferences with specific reference to Nigeria and South Africa given the existing regulatory environments in both countries. The findings of the study will assist management of commercial banks not only to better understand how customer demographics dictate their preference for bank products; it will also help bank management to effectively segment their target market in the interest of achieving effective and efficient product offering to their respective target market segments.

In his study titled "Gender-Based Retail Bank Choice Decisions in Nigeria" Omar (2007) opined that differences in the financial responsibility of men, women and students coupled with differences in orientation and preferences, the perception and choice of bank products are likely to vary significantly across demographic considerations. The study intends to encourage banking services providers to tailor their products around the preferences of their customer demographic factors for optimal performance and widest possible coverage of the market. This approach is inclusive as opposed to the traditional exclusive approach whereby financial services providers often tend to focus on the male market with financial products to the 
neglect of the female market segment (Omar, 2007). It is worthy of note that the financial management landscape has undergone rapid overhaul in recent times thus making it a much more competitive environment for all players. These changes were indicated by the emergence of many new financial institutions, introduction of new financial instruments, implementation of new financial policies and regulatory framework. Thus, the contemporary role of banks in Nigeria and South Africa has shifted from the traditional financing of trades to one of mobilising and channelling resources more effectively and efficiently to meet the ever dynamic customer needs. These changes essentially have eliminated the demographic demarcation lines among different types of customers.

More specifically, the study aims at determining the influence of education on customers' bank product appeal in Nigeria and South Africa, investigate the influence of age on customers' bank product appeal in Nigeria and South Africa, establish the relationship between customers' gender and bank product appeal in Nigeria and South Africa, determine the influence of customers' socio-economic status on their bank product decision in Nigeria and South Africa, and also to investigate the influence of personal income on customers' bank product appeal in Nigeria and South Africa. The findings of this study will be useful as they provide pertinent information for bank managers in product innovation, marketing strategy, and policy formulation to enhance optimal reach of their target markets. The rest of the paper is structured as follows: Section 2 presents the review of related literature, Section 3 is centred on methodology, data presentation and estimation technique employed. Section 4 examines and discusses the empirical results of the study. The paper closes with concluding remarks and implications of the results.

\section{Literature Review}

Bank selection criteria: Copious literature exists in the domain of bank selection criteria although they are mostly country-specific as they are subject to cultural, economic and legal environments that are unique to individual country (Rao and Sharma, 2010). Thus, while such studies have contributed substantially to the literature on bank selection, their findings may not be applicable to other countries. Diverse factors have been considered to impact hugely the selection of banks by customers. Empirical studies have identified safety of funds and availability of technology based services as being more critical and of high significance (Omar, 2007; Aregbeyen, 2011). Other influencing factors that also impact on selection of banks by customers are efficient service delivery, speed of transaction, friendly staff, overdraft privileges, third party recommendation, bank reputation credit availability, low service charge, range of services, convenient location, bank size, and bank ownership (Omar, 2007). Munusamy, DeRun, Chelliah, and Annamalah (2012) opined that the perception of five factors influence customers' preference for one bank product over the other, these are: ease of operation, reliability, convenience of usage, low level of risk, and safety of usage. Rao and Sharma (2010) identified the various factors that affect bank product preferential decisions to include: reliability, convenience, assurance, value added services, accessibility and responsiveness. Hinson, Dasah and Owusu-Frimpong (2009) in a study aimed at understanding the key motivations for maintaining accounts within banks in Ghana find that proximity is the determinant factor for opening an account by a customer with a bank. Most of the previous studies have focussed on analysing bank choice criteria (Narteh and Owusu-Frimpong, 2010; Albert, Njanike, and Mukucha, 2011; Nkamnebe and Ukenna, 2011) whereas, studies focussing on the influence of demographic variables on choice of bank products have been very limited. This is the gap in the body of existing knowledge that this study intend to fill.

Customer demographic profile and bank product selection: Considering the fact that the needs and preferences of customers are ever changing, it is imperative for providers of services being demanded by the customer to be wary of this dynamism to be able to evolve strategies to cope with the situation. Thus an informed knowledge of how customers select product will help banks to identify which product to develop for which market and also determine the appropriate marketing strategies needed to attract new customers and retain existing ones (Kaynak, Kucukemiroglu and Odabasi, 1991; Blankson, Omar and Cheng, 2009). It is worthy of note that the business environment in contemporary times is practically undergoing a major revolution in the way customers buy, shop, and eventually decide to either come back or take their business elsewhere. Thus, companies are increasingly realising that the balance of power is progressively shifting from sellers to buyers. This is the principle of contemporary marketing strategies - treating the customer as a king (Lopez et al. 2007). This is considering the fact that the customers are the reason for an organization to be in 
business for without them the organization cannot be. For example, customers need exactly what they want, at the right time and place that they want it, with a high specification and at the lowest possible price. In addition, businesses must make customers feel special or else they will take their money to another business that can provide all what they want. Hence, it is inevitable that banks identify main factors that determine the basis upon which customers select their preferred products among various existing categories (Aregbeyen, 2011).

Studies have underscored the need for understanding customer satisfaction, customers' bank selection criteria, and role of customers' demographic factors in shaping customers' awareness and usage of Islamic bank products/services (Dusuki and Abdullah, 2007; Metawa and Almossawi, 1998; Wilson, 1995). Aregbeyen (2011) in his study on the determinants of bank selection choices by customers find that education correlates positively with banking habits. His study reveal that $52 \%$ of the studied population with tertiary education have bank accounts, $32 \%$ of the respondents with secondary education have bank accounts, $12 \%$ with primary education and $4 \%$ with no education have bank accounts respectively. In a similar study by Muzividzi, Mbizi, and Mukwazhe (2013) in their analysis of factors that influence internet banking adoption among bank customers posit that an association exist between internet banking and a bank's customer educational level. Education was deemed a prerequisite in enhancing the smooth adoption of internet banking and hence one should have a significant level of education to take up the technology. Thus going by consumer behaviour theory, banks adopt the innovative technology of internet / electronic banking to prevent customer switching from their bank to other banks in the name of looking for better services. AlSomali, Gholami, and Clegg (2009) discover that trust and education has a significant impact on customers' attitudes towards using internet banking. For people to therefore adopt internet banking, they need to be educated. This view was corroborated by Howcroft, Hamilton, and Hewer (2002), who argue that the demographic characteristics that describe typical internet banking customers include education among other demographic variables.

In their study of gender and finance in Sub - Saharan Africa, Aterido, Beck, and Iacovone (2011) observed that one of the critical determinants of the extent of use of financial services in sub-Saharan African countries is education. Their study discovered that with education the normally observed gender difference in access to banking services is no longer in existence. Education is thus found to be a strong predictor of the use of banking services. Consequent upon the arguments in favour of education as a pivotal determinant of specific bank product, we thus hypothesise as follows:

H1: Bank products' appeal is significantly influenced by Education level of the customers of banks in Nigeria and South Africa.

The role of employment status on bank product preference has also been well documented in empirical literature. Employment status was found to correlate positively with banking habits (Aregbeyen, 2011; Asikhia, 2011; Ukenna, Okoye, Ugwuomu and Monanu, 2012). This explains why current account holders are basically from the high income group. The low income category by implication generally prefer savings account. Tootelian and Gaedeke (1996) argue that employees with high status often develop a need for a wider range of financial services. Thus, those people with high employment status often hold multiple accounts and made use of diverse services of the bank compared to their low employment counterparts. In their study aimed at investigating whether women are disadvantaged in the issue of gender and finance, Aterido, Beck, and Iacovone (2011) posit that employment status is one of the critical factors that determines the extent of usage of financial services in Sub - Saharan Africa. The effect of income level on the use of financial services has been well investigated by researchers. It is worthy of note that barely $20-30 \%$ of the population in developing countries have access to financial services excluding about $70-80 \%$ of the population from having access to financial services. This is in sharp contrast to the case of developed economies where about $90-99 \%$ of the population have access to financial services (World savings bank institute, 2004). The $20-30 \%$ of the population in the developing economies that do have access to financial services basically comprises of the high income group with the low income earners suffering considerable challenges of accessing financial services. In view of these arguments in support of socio - economic status as a determinant of bank product preference, we hereby hypothesise as follows: 
H2: Bank products' appeal is significantly influenced by Socio-economic status of customers in Nigeria and South Africa.

H3: Personal income has a significant influence on customers' bank products appeal in Nigeria and South Africa.

Furthermore, empirical studies have also revealed that adopters of innovations tend to be more educated, have higher status occupations and higher incomes than non-adopters (Kolodinsky, and Hilgert, 2004; Mokhlis, Salleh, and Mat, 2011; Okoe, Osarenkhoe, and Hinson, 2013). In a study in Hong Kong, the following demographic variables were considered to be important ones in customers' adoption behaviour in banking: gender, age, household income, educational level, and occupation (Wan, Luk, \& Chow, 2005). In another recent study, Cohen, Gan, Hwa and Chong (2006) asserted that customers' age groups and level of education contributed to explaining respondents' propensity to stay with their current banks. Metawa and Almossawi (1998) in a study on behaviour of Islamic bank customers in Bahrain considered age, income, level of education, and nationality as important socio-demographic variables in associated with customer behaviours. In their investigations on the factors that influence choice of internet banking (Flynn and Goldsmith, 1993; Matila, Grandey and Fisk, 2003; Gan, Clemens, Limsombunchai, and Weng, 2006; Chiemeke, Evwiekpaefe, and Chete, 2006; Bauer and Hein, 2006; Sakkthivel, 2006; Awamleh and Fernandes, 2006; Berger and Gensler, 2007) find that prominent among influencing factors are income level and age. Their studies reveal that younger customer tend to opt for internet banking more than adults. On the other hand, their studies discover that higher income customers prefer internet banking more than low income earning customers. The influence of age on bank product appeal to customers has been extensively documented in literature. Fozia (2013) in an attempt to determine the customer's perception toward the e - banking services find that different age group of customers and different occupation group of customers have different perception toward the e - banking services. The study reveals that age plays a significant effect on customers' perception of e - banking service quality. Furthermore, research has linked age and adoption of technologies with younger persons being more likely to adopt e - banking products than old people (Zeithaml and Gilly, 1987; Trocchia and Janda, 2000; Karjaluoto, Mattila, and Pento, 2002. Based on literature we thus hypothesize as follows:

H4: Age has a significant influence on customers' bank products appeal in Nigeria and South Africa.

The influence of gender on bank products appeal has been subjected to considerable empirical investigations. Traditionally, bank products used to be tailored for the male gender considering the original notion that women are supposed to be full housewives - a practice that is fast fading out due to the advent of civilization. With increasing awareness of the need for both male and female alike to embrace education the bias of education in favour of the male against the female is fast fizzling out. Hence, both male and female are now opting for banking products and services alike (Ukenna, Okoye, Ugwuomu and Monanu 2012). Considering these argument in favour of the influence of gender on bank product preference we thus hypothesise as follows:

\section{H5: Gender has a significant influence on customers' bank products appeal in Nigeria and South Africa}

Considering the foregoing, it is arguable therefore that the knowledge and of the influence of demographic factors on preferential decisions for specific bank products will enable effective marketing of the products to the right audience thus improving on the productivity of the financial system which by extension will enhance efficiency and effectiveness of the system with consequential positive impact on the performance not only of the banks but also of the economy.

Theoretical Framework: There are different theories that can be used to explain the relationship between bank customers' demographic variables influence on bank product appeal. These include the competition theory and choice theory which underpins this study. Levin and Milgrom (2004) posit that individual decision - making forms the basis of nearly all microeconomic analysis. In the standard view, rational choice is defined to mean the process of determining what options are available and then choosing the most preferred one among available alternatives. This is the principle on which rational choice is based. It is an optimization based approach which is one of maximising a real - valued utility function. The rational choice theory 
provides useful sights on the choice or selection behaviour of individual customer, while the competition theory explains how firms try to win customers patronage and loyalty through service excellence, meeting customers' needs and providing innovative products. The choice theory otherwise referred to as rational choice or rational action theory is a framework for understanding and often formally modelling social and economic behaviour. In microeconomic models, rationality which basically expresses the idea of wanting more rather than less of a good is widely used as an assumption of the behaviour of individuals. According to the theory, patterns of behaviour in societies reflect the choices made by individuals in their bid to maximise their benefits and minimise their costs. In other words, people make decisions about how they should act by comparing the costs and benefits of different courses of action. Consequently, patterns of behaviour develop within the society as a result of those choices.

Decisions are said to be rational when an action is chosen given one's preference amongst existing alternative courses of action that gives desired outcome. The validity of rational decision making is rooted in two complementary assumptions namely completeness and transitivity. The principle of completeness holds that all actions of the individual can be ranked in an order of preference while transitivity requires that if choice $\mathrm{A}$ is preferred to $\mathrm{B}$, and $\mathrm{B}$ is preferred to $\mathrm{C}$, then $\mathrm{A}$ is preferred to $\mathrm{C}$. These assumptions jointly form the result that given a set of exhaustive and exclusive actions to choose from, an individual can rank them in order of his preference, and that his preferences are consistent. Competition theory on the other hand describes the existence within a market for some goods or service of a sufficient number of buyers and sellers such that no single market participant has enough influence to determine the going price of a good or service. Competition occurs when two or more organizations act independently to supply their product to the same group of consumers. Direct competition exists where organizations produce similar products that appeal to the same group of consumers. Indirect competition exists when different firms offer to the same market goods or services which although is not in head to head competition but still competes with the same money in the buyers' pockets. Competition, whether direct or indirect cause firms to develop new products and technologies which is to the benefit of the buyers since it give consumers greater selection and better and improved products.

By implication therefore, the competitive strategy of the firm is contingent upon consumers' preferential choice which tend to influence firms' productive decision towards the satisfaction of the consumers. Given the rationality of human decisions in which people normally compare the costs and benefits of certain actions is much easy to observe in respect of bank products selection behaviour of customers. This is simply because the average person wants to get the most useful products / services at the lowest price; this will be compared from bank to bank before a conclusive decision is taken. By this reasoning, people will choose the bank whose products offer the greatest reward or benefits at the lowest cost. Kaynak, Kucukemiroglu and Odabasi (1991) argue that considering the competitiveness of the banking services with banks not only competing among each other, but also with non-banks and other financial institutions, the banks cannot but keep initiating new products and services for competitiveness. However, since most bank products development is easy to duplicate banks therefore can only distinguish themselves on the basis of price and quality. Thus, customers' retention is the only effective tool that banks can use to gain a strategic advantage and survive in the contemporary ever-increasing competitiveness of the banking environment. This paper differs from other studies primarily in that while other studies focus on causality of growth from savings perspective, and some others concentrated on influence of demographic variables on choice of bank, this study aimed at investigating the influence of demographic variables on bank products appeal in the countries covered by the study. Appropriate recommendations based on findings from the study will be used to advise policy makers accordingly.

\section{Methodology}

Data Sources: The data for this study were gathered via an opinionated survey of conducted in the major economic nerve centres of Nigeria and South Africa. The sample size for Nigeria was 2,160 respondents whose questionnaires were fully completed out of 2,350 that were distributed. The size for South Africa was 1,524 out of 1,700 that were distributed. The respondents were randomly selected at the various banks through the help of trained research assistants. As required by UNISA (University of South Africa) Ethics Committee, respondents were conspicuously advised that their responses will be treated with strict 
confidentiality and will be used strictly for academic purposes and also that participation is totally voluntary. The instrument was partitioned into three. Part " $\mathrm{A}$ " sought information on respondents' demographic profile such as nationality, age, gender, education, status, and income level. Part "B" is designed to capture information on access to banking of the respondents. Information required are on type of account(s) held, bank branch proximity, most appealing bank product, product accessibility, benefits of automated bank products, dislikes of automated bank products. Finally, part "C" was designed to elicit information on factors hindering access to banking services. The questionnaire consists of both open as well as closed ended questions with appropriately graduated response scales. The population of the study comprises of all the bank customers in the respective territory covered by the study in each of the two countries selected for the study. To arrive at such a comprehensive list of customers would require the various banks to reveal their customers' list together with their profiles.

The banks for competitive privacy reasons are unwilling to release such data. Hence, a non-probability rather than a probability sampling method was adopted for the study. The questionnaire being a self-developed instrument was validated. Prior to the validation of the instrument, the Kaise-Meyer-Olkin (KMO) measure of sampling adequacy was conducted. The 0.808 coefficient obtained for the KMO test is considered strong enough to conduct the factor analysis. Also, the p - value obtained for the Bartlett test (0.000) is also indicative of strong enough correlation structure to support factor analysis. Factor analysis was thus carried out on the variables using principal components extraction method. Three factors were obtained at the end of the factor analysis. Thereafter, the reliability statistics computed at 0.6 is considered acceptable for the instrument. Thus, the questionnaire was thus administered.

Sample size and sampling technique: Purposive sampling technique was adopted for the study considering the fact that the characteristics of the target population cum the unwillingness of the banks to release information concerning their customers' list and profile thus the constraints regarding the exactness of the study population do not lend the population of the study to random sampling technique. The sample size of 1,524 was consequently drawn from the various territories covered by the study in South Africa while for Nigeria; the sample size of 2,160 was used. A total of 1,700 questionnaires were administered at the various locations covered by the study in South Africa out of which 1,524 were completed and returned giving a response rate of $90 \%$ while in the case of Nigeria; 2,350 questionnaires were administered of which 2,160 were completed and retrieved giving a response rate of $92 \%$. For Nigeria the three major economic centres covered were Lagos, Ibadan and Port-Harcourt while for South Africa, the three major economic provinces covered were: Pretoria / Johannesburg, Durban / Pietermaritzburg and Cape Town. Descriptive and non parametric estimations were employed in the analysis of the data generated by the study.

\section{Data analysis}

Analysis of the data began with data verification and cleaning. This action was required to ensure that the data collected are clean, correct and useful. Considering that the data are of the nominal and ordinal types, simple frequency was used for verification and cleaning of the data. By the cleaning exercise, erroneous values were replaced by system missing values. Having cleaned the data, the factor analysis was done as described above. Thereafter, various analyses were carried out in pursuit of the study objectives. The table of cross-tabulation of age group, number of accounts and types of account is as presented in table 1 below. 
Table 1: Table of age group / number and types of accounts (Regional comparison)

\begin{tabular}{|c|c|c|c|c|c|c|c|c|c|c|c|c|c|c|c|c|c|c|c|c|c|c|c|c|}
\hline \multirow{3}{*}{$\begin{array}{l}\text { Age group } \\
\text { (Years) }\end{array}$} & \multicolumn{12}{|c|}{ Number of accounts } & \multicolumn{12}{|c|}{ Types of account } \\
\hline & \multicolumn{6}{|c|}{ Nigeria } & \multicolumn{6}{|c|}{ South Africa } & \multicolumn{6}{|c|}{ Nigeria } & \multicolumn{6}{|c|}{ South Africa } \\
\hline & 1 & 2 & 3 & $>3$ & $\mathbf{0}$ & Total & 1 & 2 & 3 & $>3$ & $\mathbf{0}$ & Total & C & $\mathbf{S}$ & D & CD & MM & Total & C & $\mathbf{S}$ & D & CD & MM & Total \\
\hline $18-25$ & 95 & 137 & 34 & 2 & 73 & 341 & 198 & 34 & 9 & 2 & 109 & 352 & 2 & 267 & 0 & 0 & 5 & 274 & 12 & 228 & 0 & 0 & 9 & 249 \\
\hline $26-30$ & 67 & 255 & 66 & 10 & 67 & 465 & 146 & 52 & 9 & 5 & 78 & 290 & 35 & 360 & 1 & 1 & 13 & 410 & 17 & 193 & 1 & 0 & 0 & 211 \\
\hline $31-35$ & 56 & 181 & 55 & 14 & 121 & 427 & 135 & 52 & 7 & 2 & 98 & 294 & 41 & 267 & 2 & 0 & 33 & 343 & 28 & 165 & 1 & 0 & 2 & 196 \\
\hline $36-40$ & 43 & 189 & 69 & 11 & 229 & 541 & 179 & 41 & 14 & 5 & 53 & 292 & 41 & 274 & 3 & 2 & 35 & 355 & 33 & 204 & 0 & 1 & 2 & 240 \\
\hline Above 40 & 30 & 96 & 38 & 13 & 209 & 386 & 165 & 57 & 20 & 7 & 47 & 296 & 16 & 168 & 5 & 0 & 31 & 220 & 42 & 206 & 0 & 0 & 1 & 249 \\
\hline tal & 291 & 858 & 262 & 50 & 669 & 2160 & 823 & 236 & 59 & 21 & 385 & 1524 & 135 & 1336 & 11 & 3 & 117 & 1602 & 132 & 996 & 2 & 1 & 14 & 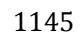 \\
\hline
\end{tabular}

Key: C-Current a/c, S-Savings a/c, D-Domiciliary a/c, CD-Certificate of deposit, MM-Money market a/c

From table 1 above table it is observable that the number and type of accounts held by respondents varied significantly with age group. For both countries, the highest number of accounts held by respondents falls between the $36-40$ years age group in the case of Nigeria and above 40 years in the case of South Africa. This affirms the hypothesis that age group has a significance effect on choice of bank product. Further, in the case of Nigeria, $54 \%$ of the respondents have 2 accounts whereas, in the case of South Africa, the figure is barely $21 \%$. This is arguably due to the fact that with financial inclusion policy being practiced in Nigeria access to financial services is relatively easier compared to South Africa where the regulatory framework emphasizes strictness in verification of customer identity before any financial transaction is concluded - a condition that has very high potential to disenfranchise the socially and financially disadvantaged. From the above table 2, a significant influence of age group is observable on the bank product usage across the two countries, it is however noteworthy that accessibility of innovative products is much higher in South Africa that in Nigeria. This is due to the fact that South Africa has a better technological infrastructure compared to Nigeria.

Table 2: Table of age group / bank product and accessibility (Regional comparison)

\begin{tabular}{|c|c|c|c|c|c|c|c|c|c|c|c|c|c|c|c|c|c|c|c|c|c|c|}
\hline \multirow{3}{*}{$\begin{array}{l}\text { Age } \\
\text { group } \\
\text { (Years) }\end{array}$} & \multicolumn{12}{|c|}{ Bank products } & \multicolumn{10}{|c|}{ Bank products accessibility } \\
\hline & \multicolumn{6}{|c|}{ Nigeria } & \multicolumn{6}{|c|}{ South Africa } & \multicolumn{5}{|c|}{ Nigeria } & \multicolumn{5}{|c|}{ South Africa } \\
\hline & ATM & MP & IB & TB & CCDM & Total & ATM & MP & IB & TB & CDM & Total & RA & FA & SA & NA & Total & RA & FA & SA & NA & Total \\
\hline $18-25$ & 273 & 5 & 0 & 1 & 0 & 279 & 252 & 21 & 7 & 4 & 7 & 291 & 70 & 191 & 15 & 28 & 304 & 150 & 107 & 17 & 45 & 319 \\
\hline $26-30$ & 401 & 13 & 5 & 0 & 0 & 419 & 222 & 14 & 21 & 3 & 12 & 272 & 52 & 333 & 25 & 14 & 424 & 132 & 106 & 10 & 15 & 265 \\
\hline $31-35$ & 345 & 5 & 1 & 0 & 2 & 353 & 191 & 11 & 22 & 5 & 9 & 238 & 39 & 296 & 13 & 32 & 380 & 86 & 117 & 15 & 50 & 268 \\
\hline $36-40$ & 352 & 6 & 0 & 1 & 0 & 359 & 210 & 26 & 23 & 4 & 4 & 267 & 33 & 301 & 20 & 67 & 421 & 109 & 139 & 10 & 19 & 277 \\
\hline $\begin{array}{l}\text { Above } \\
40\end{array}$ & 222 & 4 & 0 & 0 & 1 & 227 & 237 & 20 & 25 & 2 & 6 & 290 & 65 & 156 & 2 & 7 & 230 & 138 & 142 & 6 & 2 & 288 \\
\hline Total & 1593 & 33 & 6 & 2 & 3 & 1637 & 1112 & 92 & 98 & 18 & 38 & 1358 & 259 & 1277 & 75 & 148 & 1759 & 615 & 611 & 58 & 133 & 1417 \\
\hline
\end{tabular}

Seldom accessible, NA-Not accessible 
Table 3: Table of education status / number and types of accounts (Regional comparison)

\begin{tabular}{|c|c|c|c|c|c|c|c|c|c|c|c|c|c|c|c|c|c|c|c|c|c|c|c|c|}
\hline \multirow{3}{*}{$\begin{array}{l}\text { Educ- } \\
\text { Ation }\end{array}$} & \multicolumn{12}{|c|}{ Number of accounts } & \multicolumn{12}{|c|}{ Types of account } \\
\hline & \multicolumn{6}{|c|}{ Nigeria } & \multicolumn{6}{|c|}{ South Africa } & \multicolumn{6}{|c|}{ Nigeria } & \multicolumn{6}{|c|}{ South Africa } \\
\hline & 1 & 2 & 3 & $>3$ & $\mathbf{0}$ & Total & 1 & 2 & 3 & $>3$ & $\mathbf{0}$ & Total & C & $\mathbf{S}$ & D & CD & MM & Total & C & $\mathbf{S}$ & D & CD & MM & Total \\
\hline BM & 36 & 34 & 6 & 2 & 461 & 539 & 335 & 36 & 6 & 2 & 176 & 555 & 15 & 76 & 0 & 0 & 65 & 156 & 16 & 360 & 1 & 0 & 8 & 385 \\
\hline M & 119 & 174 & 38 & 7 & 216 & 554 & 304 & 102 & 22 & 1 & 167 & 596 & 15 & 328 & 3 & 3 & 48 & 397 & 39 & 384 & 1 & 0 & 5 & 429 \\
\hline Dip & 75 & 303 & 69 & 8 & 13 & 468 & 94 & 45 & 12 & 3 & 29 & 183 & 34 & 420 & 0 & 0 & 2 & 456 & 34 & 120 & 0 & 0 & 0 & 154 \\
\hline Deg & 56 & 302 & 111 & 29 & 9 & 507 & 84 & 43 & 13 & 9 & 11 & 160 & 61 & 434 & 4 & 0 & 2 & 501 & 31 & 116 & 0 & 1 & 1 & 149 \\
\hline$M \& D$ & 5 & 45 & 38 & 4 & 0 & 92 & 6 & 10 & 6 & 6 & 2 & 30 & 10 & 78 & 4 & 0 & 0 & 92 & 12 & 16 & 0 & 0 & 0 & 28 \\
\hline Total & 291 & 858 & 262 & 50 & 699 & 2160 & 823 & 236 & 59 & 21 & 385 & 1524 & 135 & 1336 & 11 & 3 & 117 & 1602 & 132 & 996 & 2 & 1 & 14 & 1145 \\
\hline
\end{tabular}

From tables 3 and four, the number and types of accounts held by customers vary slightly with education status. This may be attributable to the fact that the percentage of the population with education drops as qualification increases.

Table 4: Table of education status / bank products and accessibility (Regional comparison)

\begin{tabular}{|c|c|c|c|c|c|c|c|c|c|c|c|c|c|c|c|c|c|c|c|c|c|c|}
\hline \multirow[t]{3}{*}{ Education } & \multicolumn{12}{|c|}{ Bank products } & \multicolumn{10}{|c|}{ Bank products accessibility } \\
\hline & \multicolumn{6}{|c|}{ Nigeria } & \multicolumn{6}{|c|}{ South Africa } & \multicolumn{5}{|c|}{ Nigeria } & \multicolumn{5}{|c|}{ South Africa } \\
\hline & ATM & MP & IB & TB & CCDM & Total & ATM & MP & IB & TB & CDM & Total & RA & FA & SA & NA & Total & RA & FA & SA & NA & Total \\
\hline BM & 181 & 2 & 0 & 0 & 0 & 183 & 420 & 6 & 10 & 4 & 15 & 455 & 46 & 121 & 12 & 110 & 289 & 138 & 279 & 18 & 75 & 510 \\
\hline M & 397 & 4 & 5 & 1 & 1 & 405 & 455 & 40 & 21 & 6 & 17 & 539 & 93 & 291 & 16 & 24 & 424 & 261 & 217 & 30 & 49 & 557 \\
\hline Dip & 439 & 15 & 1 & 0 & 1 & 456 & 122 & 23 & 24 & 5 & 4 & 178 & 35 & 399 & 17 & 5 & 456 & 99 & 59 & 6 & 6 & 170 \\
\hline Deg & 488 & 9 & 0 & 1 & 1 & 501 & 101 & 20 & 33 & 3 & 0 & 157 & 71 & 394 & 25 & 8 & 498 & 93 & 53 & 4 & 2 & 152 \\
\hline$M \& D$ & 88 & 3 & 0 & 0 & 0 & 92 & 14 & 3 & 10 & 0 & 2 & 29 & 14 & 72 & 5 & 1 & 92 & 24 & 3 & 0 & 1 & 28 \\
\hline Total & 1593 & 33 & 6 & 2 & 3 & 1637 & 1112 & 92 & 98 & 18 & 38 & 1358 & 259 & 1277 & 75 & 148 & 1759 & 615 & 611 & 58 & 133 & 1417 \\
\hline
\end{tabular}

Table 5: Table of gender / number and types of accounts (Regional comparison)

\begin{tabular}{|c|c|c|c|c|c|c|c|c|c|c|c|c|c|c|c|c|c|c|c|c|c|c|c|c|}
\hline \multirow[t]{3}{*}{ Gender } & \multicolumn{12}{|c|}{ Number of accounts } & \multicolumn{12}{|c|}{ Types of account } \\
\hline & \multicolumn{6}{|c|}{ Nigeria } & \multicolumn{6}{|c|}{ South Africa } & \multicolumn{6}{|c|}{ Nigeria } & \multicolumn{6}{|c|}{ South Africa } \\
\hline & 1 & 2 & 3 & $>3$ & 0 & Total & 1 & 2 & 3 & $>3$ & 0 & Total & C & $\mathbf{S}$ & D & CD & MM & Total & C & $\mathbf{S}$ & D & CD & MM & Total \\
\hline Male & 144 & 330 & 118 & 30 & 299 & 921 & 487 & 123 & 27 & 14 & 198 & 849 & 73 & 545 & 5 & 1 & 32 & 656 & 83 & 561 & 2 & 1 & 7 & 654 \\
\hline Female & 147 & 528 & 144 & 20 & 400 & 1239 & 336 & 113 & 32 & 7 & 187 & 675 & 62 & 791 & 6 & 2 & 85 & 946 & 49 & 453 & 0 & 0 & 7 & 491 \\
\hline Total & 291 & 858 & 262 & 50 & 699 & 2160 & 823 & 236 & 59 & 21 & 385 & 1524 & 135 & 1336 & 11 & 3 & 117 & 1602 & 132 & 996 & 2 & 1 & 14 & 1145 \\
\hline
\end{tabular}

From tables 5 and 6, there is a noticeable improvement in the number of females holding bank accounts when compared with the situation in times past. This is as a result of civilization in which education has changed the orientation of the past in which only the man fends for his family. With education, women are no longer relegated to the "kitchen" but are also "rubbing shoulders" with their male counterparts in doing businesses to enable them also contribute to fending for the family. Hence, the appreciable number of women holding bank accounts. For Nigeria specifically, approximately $51.21 \%$ of the $170 \mathrm{~m}$ population are females reference the 1991 and 1996 census record; hence the higher number of females holding bank accounts compare to the males. Thus it could be inferred that gender influence choice of bank products although not so significantly (87\% female opt for savings accounts in both countries compared to $84 \%$ in the case of males in both countries). 
Table 6: Table of gender / bank products and accessibility (Regional comparison)

\begin{tabular}{|c|c|c|c|c|c|c|c|c|c|c|c|c|c|c|c|c|c|c|c|c|c|c|}
\hline \multirow[t]{3}{*}{ Gender } & \multicolumn{12}{|c|}{ Bank products } & \multicolumn{10}{|c|}{ Bank products accessibility } \\
\hline & \multicolumn{6}{|c|}{ Nigeria } & \multicolumn{6}{|c|}{ South Africa } & \multicolumn{5}{|c|}{ Nigeria } & \multicolumn{5}{|c|}{ South Africa } \\
\hline & ATM & MP & IB & TB & CCDM & Total & ATM & MP & IB & TB & CDM & Total & $\mathbf{R A}$ & FA & SA & NA & Total & $\mathbf{R A}$ & FA & SA & NA & Total \\
\hline Male & 646 & 16 & 1 & 2 & 2 & 667 & 644 & 40 & 44 & 6 & 19 & 753 & 138 & 489 & 31 & 104 & 762 & 327 & 348 & 35 & 72 & 782 \\
\hline Female & 947 & 17 & 5 & 0 & 1 & 970 & 468 & 52 & 54 & 12 & 19 & 605 & 121 & 788 & 44 & 44 & 997 & 288 & 263 & 23 & 61 & 635 \\
\hline Total & 1593 & 33 & 6 & 2 & 3 & 1637 & 1112 & 92 & 98 & 18 & 38 & 1358 & 259 & 1277 & 75 & 148 & 1759 & 615 & 611 & 58 & 133 & 1417 \\
\hline
\end{tabular}

Table 7: Table of socio-economic status / number and types of accounts (Regional comparison)

\begin{tabular}{|c|c|c|c|c|c|c|c|c|c|c|c|c|c|c|c|c|c|c|c|c|c|c|c|c|}
\hline \multirow{3}{*}{$\begin{array}{l}\text { Socio } \\
\text { Economic } \\
\text { Status } \\
\end{array}$} & \multicolumn{12}{|c|}{ Number of accounts } & \multicolumn{12}{|c|}{ Types of account } \\
\hline & \multicolumn{6}{|c|}{ Nigeria } & \multicolumn{6}{|c|}{ South Africa } & \multicolumn{6}{|c|}{ Nigeria } & \multicolumn{6}{|c|}{ South Africa } \\
\hline & 1 & 2 & 3 & $>3$ & $\mathbf{0}$ & Total & 1 & 2 & 3 & $>3$ & $\mathbf{0}$ & Total & C & $\mathbf{S}$ & D & CD & MM & Total & C & $\mathbf{S}$ & D & CD & MM & Total \\
\hline Employed & 46 & 37 & 11 & 14 & 70 & 627 & 328 & 172 & 37 & 18 & 73 & 628 & 55 & 493 & 6 & 1 & 1 & 556 & 96 & 455 & 1 & 1 & 1 & 554 \\
\hline Unemployed & 53 & 80 & 4 & 0 & 250 & 387 & 233 & 24 & 5 & 2 & 186 & 450 & 3 & 133 & 1 & 0 & 56 & 193 & 16 & 243 & 0 & 0 & 6 & 265 \\
\hline Self-employed & 135 & 361 & 131 & 32 & 356 & 1015 & 181 & 28 & 15 & 1 & 80 & 305 & 76 & 603 & 4 & 2 & 58 & 743 & 16 & 207 & 1 & 0 & 2 & 226 \\
\hline Schooling & 57 & 38 & 9 & 4 & 23 & 131 & 81 & 12 & 2 & 0 & 46 & 141 & 1 & 107 & 0 & 0 & 2 & 11 & 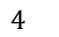 & 91 & 0 & 0 & 5 & 100 \\
\hline 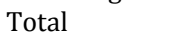 & 291 & 858 & 262 & 50 & 699 & 2160 & 823 & 236 & 59 & 21 & 385 & 1524 & 135 & 1336 & 11 & 3 & 117 & 1602 & 132 & 996 & 2 & 1 & 14 & 145 \\
\hline
\end{tabular}

Tables 7 and 8 indicated that socio - economic status does influence the number of accounts, types of account as well as bank product decision. It is observable from the tables that the employed respondents hold more accounts and also made use of bank products than the unemployed. Interestingly, the self-employed holds more accounts than the employed in Nigeria which suggests that there are more self-employed people holding bank accounts and using diverse bank products than the employed. This can be substantiated by the recent pronouncement that Nigeria now has the largest economy in Africa. A feat that was made possible by rebasing the Nigerian economy.

\begin{tabular}{|c|c|c|c|c|c|c|c|c|c|c|c|c|c|c|c|c|c|c|c|c|c|c|}
\hline \multirow{3}{*}{$\begin{array}{l}\text { Socio } \\
\text { Economic } \\
\text { status }\end{array}$} & \multicolumn{12}{|c|}{ Bank products } & \multicolumn{10}{|c|}{ Bank products accessibility } \\
\hline & \multicolumn{6}{|c|}{ Nigeria } & \multicolumn{6}{|c|}{ South Africa } & \multicolumn{5}{|c|}{ Nigeria } & \multicolumn{5}{|c|}{ South Africa } \\
\hline & ATM & MP & IB & TB & CCDM & Total & ATM & MP & IB & TB & CDM & Total & RA & FA & SA & NA & Total & RA & FA & SA & NA & Total \\
\hline Employed & 539 & 15 & 2 & 1 & 0 & 557 & 463 & 58 & 70 & 12 & 13 & 616 & 53 & 471 & 27 & 6 & 557 & 351 & 220 & 23 & 13 & 607 \\
\hline Unemployed & 219 & 4 & 0 & 0 & 0 & 223 & 307 & 9 & 6 & 2 & 11 & 335 & 13 & 204 & 4 & 128 & 349 & 120 & 179 & 20 & 100 & 419 \\
\hline Self-employed & 725 & 12 & 3 & 0 & 3 & 743 & 239 & 14 & 20 & 2 & 11 & 286 & 134 & 555 & 39 & 10 & 738 & 69 & 184 & 7 & 8 & 268 \\
\hline Schooling & 110 & 2 & 1 & 1 & 0 & 114 & 103 & 11 & 2 & 2 & 3 & 121 & 59 & 47 & 5 & 4 & 115 & 75 & 28 & 8 & 12 & 123 \\
\hline Total & 1593 & 33 & 6 & 2 & 3 & 1637 & 1112 & 92 & 98 & 18 & 38 & 1358 & 259 & 1277 & 75 & 148 & 1759 & 615 & 611 & 58 & 133 & 1417 \\
\hline
\end{tabular}

Table 9: Table of personal income / number and types of accounts (Regional comparison)

\begin{tabular}{|c|c|c|c|c|c|c|c|c|c|c|c|c|c|c|c|c|c|c|c|c|c|c|c|c|}
\hline \multirow{3}{*}{$\begin{array}{l}\text { Personal } \\
\text { income } \\
(\mathrm{N} / \mathrm{R}) \\
\left({ }^{\prime} 000\right) \\
\end{array}$} & \multicolumn{12}{|c|}{ Number of accounts } & \multicolumn{12}{|c|}{ Types of account } \\
\hline & \multicolumn{6}{|c|}{ Nigeria } & \multicolumn{6}{|c|}{ South Africa } & \multicolumn{6}{|c|}{ Nigeria } & \multicolumn{6}{|c|}{ South Africa } \\
\hline & 1 & 2 & 3 & $>3$ & $\mathbf{0}$ & Total & 1 & 2 & 3 & $>3$ & $\mathbf{0}$ & Total & C & $\mathbf{S}$ & D & CD & MM & Total & C & $\mathbf{S}$ & D & CD & MM & Total \\
\hline $1-10$ & 19 & 38 & 0 & 0 & 183 & 240 & 455 & 62 & 10 & 1 & 90 & 618 & 0 & 80 & 0 & 1 & 109 & 190 & 32 & 491 & 2 & 0 & 2 & 527 \\
\hline $11-20$ & 27 & 45 & 1 & 0 & 44 & 117 & 53 & 64 & 6 & 1 & 37 & 161 & 0 & 73 & 0 & 0 & 1 & 74 & 24 & 100 & 0 & 0 & 0 & 124 \\
\hline $21-30$ & 1 & 76 & 8 & 0 & 3 & 88 & 43 & 29 & 9 & 1 & 11 & 93 & 0 & 85 & 0 & 0 & 0 & 85 & 16 & 66 & 0 & 0 & 0 & 82 \\
\hline $31-50$ & 7 & 159 & 30 & 0 & 0 & 196 & 48 & 15 & 11 & 6 & 2 & 82 & 3 & 192 & 0 & 1 & 0 & 196 & 6 & 73 & 0 & 1 & 0 & 80 \\
\hline $51-100$ & 4 & 135 & 64 & 3 & 2 & 208 & 7 & 1 & 4 & 3 & 2 & 17 & 1 & 204 & 2 & 0 & 0 & 207 & 7 & 8 & 0 & 0 & 0 & 15 \\
\hline Above 100 & 5 & 58 & 38 & 1 & 0 & 102 & 11 & 19 & 9 & 7 & 4 & 50 & 0 & 100 & 2 & 0 & 0 & 102 & 20 & 24 & 0 & 0 & 2 & 46 \\
\hline Total & 63 & 511 & 141 & 4 & 232 & 951 & 617 & 190 & 49 & 19 & 146 & 1021 & 4 & 734 & 4 & 2 & 110 & 854 & 105 & 762 & 2 & 1 & 4 & 874 \\
\hline
\end{tabular}


Table 10: Table of personal income / bank product and accessibility (Regional comparison)

\begin{tabular}{|c|c|c|c|c|c|c|c|c|c|c|c|c|c|c|c|c|c|c|c|c|c|c|}
\hline \multirow{3}{*}{$\begin{array}{l}\text { Personal } \\
\text { income } \\
(\mathrm{N} / \mathrm{R}) \\
\left({ }^{\prime} 000\right)\end{array}$} & \multicolumn{12}{|c|}{ Bank products } & \multicolumn{10}{|c|}{ Bank products accessibility } \\
\hline & \multicolumn{6}{|l|}{ Nigeria } & \multicolumn{6}{|c|}{ South Africa } & \multicolumn{5}{|c|}{ Nigeria } & \multicolumn{5}{|c|}{ South Africa } \\
\hline & ATM & MP & IB & TB & CCDM & Total & ATM & MP & IB & TB & CDM & Total & RA & FA & SA & NA & Total & RA & FA & SA & NA & Total \\
\hline $1-10$ & 212 & 5 & 0 & 0 & 0 & 217 & 536 & 17 & 14 & 8 & 18 & 593 & 51 & 164 & 2 & 1 & 218 & 179 & 344 & 31 & 23 & 577 \\
\hline $11-20$ & 73 & 2 & 0 & 0 & 0 & 75 & 125 & 16 & 11 & 1 & 3 & 156 & 0 & 72 & 2 & 2 & 76 & 71 & 54 & 10 & 8 & 143 \\
\hline $21-30$ & 81 & 4 & 0 & 0 & 0 & 85 & 58 & 15 & 13 & 2 & 2 & 90 & 1 & 83 & 1 & 0 & 85 & 46 & 37 & 4 & 1 & 88 \\
\hline $31-50$ & 192 & 4 & 0 & 0 & 0 & 196 & 53 & 11 & 13 & 3 & 0 & 80 & 2 & 188 & 6 & 0 & 196 & 28 & 51 & 3 & 0 & 82 \\
\hline $51-100$ & 202 & 4 & 2 & 0 & 0 & 208 & 6 & 5 & 5 & 0 & 1 & 17 & 1 & 199 & 7 & 1 & 208 & 12 & 4 & 1 & 0 & 17 \\
\hline Above 100 & 97 & 4 & 1 & 0 & 0 & 102 & 24 & 4 & 18 & 0 & 3 & 49 & 1 & 94 & 7 & 0 & 102 & 45 & 2 & 0 & 0 & 47 \\
\hline Total & 857 & 23 & 3 & 0 & 0 & 883 & 802 & 68 & 74 & 14 & 27 & 985 & 56 & 800 & 25 & 4 & 885 & 381 & 492 & 49 & 32 & 954 \\
\hline
\end{tabular}

From tables 9 and 10, personal income does not influence the number of accounts held by respondents so significantly. The same observation applies to the use of innovative products of the bank.

Table 11: Chi square statistics table

\begin{tabular}{|c|c|c|c|c|c|c|}
\hline \multirow{3}{*}{$\begin{array}{l}\text { Demographic } \\
\text { Variable }\end{array}$} & \multicolumn{6}{|c|}{ Pearson Chi-Square Statistics } \\
\hline & \multicolumn{3}{|l|}{ Nigeria } & \multicolumn{3}{|c|}{ South Africa } \\
\hline & $\begin{array}{l}\text { Bank } \\
\text { Product }\end{array}$ & $\begin{array}{l}\text { No. of } \\
\text { Accounts }\end{array}$ & $\begin{array}{l}\text { Types of } \\
\text { Accounts }\end{array}$ & $\begin{array}{l}\text { Bank } \\
\text { Product }\end{array}$ & $\begin{array}{l}\text { No. of } \\
\text { Accounts }\end{array}$ & $\begin{array}{l}\text { Types of } \\
\text { Accounts }\end{array}$ \\
\hline \multirow[t]{2}{*}{ Age } & 23.441 & 273.867 & 96.481 & 29.227 & 65.108 & 48.630 \\
\hline & $(0.102)$ & $(0.000)^{* *}$ & $(0.000)^{* *}$ & $(0.080)$ & $(0.000)^{* *}$ & $(0.000)^{* *}$ \\
\hline \multirow[t]{2}{*}{ Gender } & 6.028 & 18.481 & 18.743 & 17.731 & 11.483 & 6.087 \\
\hline & $(0.197)$ & $(0.001)^{* *}$ & $(0.001)^{* *}$ & $(0.003)^{* *}$ & $(0.022)^{*}$ & $(0.029)^{*}$ \\
\hline \multirow{2}{*}{ Income } & 8.446 & 721.784 & 448.021 & 186.529 & 303.407 & 119.587 \\
\hline & $(0.585)$ & $(0.000)^{* *}$ & $(0.000)^{* *}$ & $(0.000)^{* *}$ & $(0.000)^{* *}$ & $(0.000)^{* *}$ \\
\hline \multirow[t]{2}{*}{ Education } & 12.264 & 1334.977 & 412.190 & 178.318 & 263.455 & 94.027 \\
\hline & $(0.726)$ & $(0.000)^{* *}$ & $(0.000)^{* *}$ & $(0.000)^{* *}$ & $(0.000)^{* *}$ & $(0.000)^{* *}$ \\
\hline Employment & 13.917 & 517.448 & 203.323 & 71.027 & 233.606 & 59.313 \\
\hline Status & $(0.306)$ & $(0.000)^{* *}$ & $(0.000)^{* *}$ & $(0.000)^{* *}$ & $(0.000)^{* *}$ & $\left(0.000^{* *}\right)$ \\
\hline
\end{tabular}

P-values are in parentheses (* $10 \%$ significance; $* * 5 \%$ significance)

The results obtained in the table 11 above (high Chi-Square statistics coupled with very low probability values) indicate highly significant association between the various demographic variables and the dependent variables (bank products, number of accounts and types of accounts) with the singular exception of bank products association with the explanatory variables in Nigeria. This is apparently due to the poor condition of infrastructural facility in Nigeria compared to South Africa. 
Table 12: Correlation Table (South Africa)

\begin{tabular}{|c|c|c|c|c|c|c|c|c|}
\hline Correlates & Age & Gender & Education & Status & Income & No of a/c & Acct type & Bank Pdt \\
\hline Age & (1) & $(-0.043)$ & $(0.111)^{* *}$ & $(-0.052)$ & $(-0.313)^{* *}$ & $(0.041)$ & $(-0.111)^{* *}$ & $(0.017)$ \\
\hline Gender & $(-0.043)$ & (1) & $(0.105)^{* *}$ & $(-0.103)^{* *}$ & $(0.089)^{* *}$ & $(0.038)$ & $(-0.009)$ & $(0.111)^{* *}$ \\
\hline Education & $(0.111)^{* *}$ & $(0.105)^{* *}$ & (1) & $(-0.346)^{* *}$ & $(0.703)^{* *}$ & $(0.323)^{* *}$ & $(-0.179)^{* *}$ & $(0.282)^{* *}$ \\
\hline Status & $(-0.052)$ & $(-0.103)^{* *}$ & $(0.346)^{*}$ & (1) & $(0.323)^{* *}$ & $(-0.177)^{* *}$ & $(0.153)^{* *}$ & $(-0.099)^{* *}$ \\
\hline Income & $(0.313)^{*}$ & $(0.089)^{* *}$ & $(0.703)^{* *}$ & $(-0.323)^{*}$ & (1) & $(0.420)^{* *}$ & $(-0.162)^{* *}$ & $(0.325)^{* *}$ \\
\hline No of $a / c$ & $(0.041)$ & $(0.038)$ & $(0.323)^{* *}$ & $(-0.177)^{* *}$ & $(0.420)^{* *}$ & (1) & $(0.086)^{*}$ & $(0.258)^{* *}$ \\
\hline Acct type & $(-0.111)^{* *}$ & $(-0.009)$ & $(-0.179)^{* *}$ & $(0.153)^{* *}$ & $(-0.162)^{* *}$ & $(0.086)^{*}$ & (1) & $(0.011)$ \\
\hline Bank Pdt & $(0.017)$ & $(0.111)^{* *}$ & $(0.282)^{* *}$ & $(0.099)^{* *}$ & $(0.325)^{* *}$ & $(0.258)^{* *}$ & $(0.011)$ & (1) \\
\hline
\end{tabular}

Correlation coefficient is in parenthesis

** Correlationis significant at the 0.01 level (2-tailed)

* Correlationis significant at the 0.05 level (2-tailed)

Table 13: Correlation Table (Nigeria)

\begin{tabular}{|c|c|c|c|c|c|c|c|c|}
\hline Correlates & Age & Gender & Education & Status & Income & No of a/c & Acct type & Bank Pdt \\
\hline Age & (1) & $(0.095)^{* *}$ & $(-0.225)^{* *}$ & $(0.175)^{* *}$ & $(-0.172)^{* *}$ & $(0.357)^{* *}$ & $(0.281)^{* *}$ & $(-0.040)$ \\
\hline Gender & $(0.095)^{* *}$ & (1) & $(0.014)$ & $(0.004)$ & $(-0.053)$ & $(0.068)^{*}$ & $(0.042)$ & $(0.014)$ \\
\hline Education & $(-0.225)^{* *}$ & $(0.014)$ & (1) & $(-0.321)^{* *}$ & $(0.566)^{* *}$ & $(-0.469)^{* *}$ & $(-0.531)$ & $(0.046)$ \\
\hline Status & $(0.175)^{* *}$ & $(0.004)$ & $(-0.321)^{* *}$ & (1) & $(-0.132)^{* *}$ & $(0.266)^{* *}$ & $(0.219)^{* *}$ & $(-0.020)$ \\
\hline Income & $(0.172)^{* *}$ & $(0.053)$ & $(0.566)^{* *}$ & $(0.132)^{* *}$ & (1) & $(0.437)^{* *}$ & $(0.561)^{* *}$ & $(0.035)$ \\
\hline No of a/c & $(0.357)^{* *}$ & $(0.068)^{*}$ & $(-0.469)^{* *}$ & $(0.266)^{* *}$ & $(-0.437)^{* *}$ & (1) & $0.791)^{* *}$ & $(0.001)$ \\
\hline Acct type & $(0.281)^{* *}$ & $(0.042)$ & $(-0.531)^{* *}$ & $(0.219)^{* *}$ & $(-0.561)^{* *}$ & $(0.791)^{* *}$ & (1) & $(-0.019)$ \\
\hline Bank Pdt & $(-0.040)$ & $(0.014)$ & $(0.046)$ & $(-0.020)$ & $(0.035)$ & $(0.001)$ & $(0.019)$ & (1) \\
\hline
\end{tabular}

Correlation coefficient is in parenthesis

** Correlation is significant at the 0.01 level (2-tailed)

* Correlation is significant at the 0.05 level (2-tailed)

The correlation analysis was carried out to test the five hypotheses in the case of South Africa. The correlation analyses results reflected in tables $12 \&$ 13 suggest that each of the five variables is significant either at 0.01 or 0.05 levels with 2-tailed test in both South Africa and Nigeria respectively. These results corroborated the ones obtained from the Chi-Square statistics affirming the significance of the relationship between demographic variables and choice of bank products by the customers. 
Table 14: Test of Robustness

\begin{tabular}{|c|c|c|c|c|}
\hline \multirow[t]{2}{*}{ Variables } & \multicolumn{2}{|l|}{ ANOVA } & \multicolumn{2}{|c|}{ ROBUST TEST (Brown-Forsythe) } \\
\hline & F-Statistics & Sig. & B-F Stat & Sig. \\
\hline Age & 107845.201 & 0.000 & 108186.574 & 0.000 \\
\hline Gender & 8.441 & 0.000 & 8.457 & 0.000 \\
\hline Education & 59.567 & 0.000 & 59.214 & 0.000 \\
\hline Status & 22.659 & 0.000 & 22.250 & 0.000 \\
\hline Income & 20.158 & 0.000 & 19.924 & 0.000 \\
\hline No of accounts & 9.437 & 0.000 & 9.419 & 0.000 \\
\hline Type of accounts & 11.781 & 0.000 & 11.604 & 0.000 \\
\hline Type of products & 1.204 & 0.307 & 1.206 & 0.306 \\
\hline
\end{tabular}

Source: Authors computation

Further, the ANOVA and Brown-Forsythe test of robustness were conducted and the results were as shown in table 14. The results suggest that the assumptions of normality and homogeneity of variances across samples do not hold thereby justifying the use of non-parametric method of analysis. The results validate the findings of the study and affirm its robustness.

Discussion: This study investigates the influence of demographic attributes on bank products appeal to customers in Nigeria and South Africa. The results of the analyses are as presented in the tables 1-11. The study made use of primary data generated from the two countries. Non parametric analysis was adopted considering the fact that the data were categorical in nature. The results suggest that demographic variables do have a significant influence on customers bank products appeal in the two countries selected for the study. The only exception being the insignificant association obtained between more demographic variables and bank products for Nigeria compared to the case of South Africa. This is obviously due to the poor infrastructural development of the Nigerian nation compared to South Africa. The observed significant relationship between education and bank product appeal is consistent with the various demographic variables and the explained variables is consistent with the finding of Aregbeyen (2011) who in his study observed that $52 \%$ of the population he studied with tertiary education have bank accounts, while $32 \%$ with secondary education have bank accounts while $12 \%$ and $4 \%$ have primary education and no education respectively. Several other studies also supported the findings of this study which include (Mokhlis, Salleh, and Mat, 2011; Okoe, Osarenkhoe, and Hinson, 2013; Wan, Luk, \& Chow, 2005; Cohen, Gan, Hwa and Chong, 2006; Ukenna, Okoye, Ugwuomu and Monanu 2012). Correlation analysis was carried out to complement the cross - tabulation and Chi - Square test. From the correlation analysis, it is apparent that there exists a significant relationship between bank products appeal and educational level. The effect in South Africa is however more pronounced than that of Nigeria apparently due to the financial inclusion policy entrenched in the regulatory policy of the country. This is equally true of personal income.

\section{Conclusion}

The paper concludes that there exist significant relationships between bank customers' demographic variables and bank products appeal across Nigeria and South Africa. The study also reveals that the influence of demographic variables on bank innovative products appeal in Nigeria is not significant owing to the poor state of infrastructural facility. The import of these findings places an obligation on the regulatory authorities of Nigerian financial system to consider the need for infrastructural upgrade in their policy decisions. Also, the South African Financial Regulatory Agency is advice to relax the regulatory framework a little to be able to draw more of the unbanked self - employed populace. This no doubt will boost the economic performance further. Moreover, the findings of this study are expected to inform banks managements' strategies for effective and efficient coverage of their target markets. These will promote efficiency of the respective financial systems of these countries.

Recommendations: As banking environment becomes progressively sophisticated, it is needful that banks become more customer-centric owing to the significance influence of demographic variables in customers' preference of bank products. This will enhance effectiveness and uniqueness of value offering to their 
customer segments thereby promoting competitiveness. Further, the study recommends policy intervention from the regulators to drive infrastructural upgrades to better reach customers with diverse products. Finally, a more financial inclusion policy is required to reduce the unbanked populace thereby promoting better financial intermediation role of banks in the two countries thereby boosting economic performance. Subsequent studies can extend the current discourse by looking into the issue of gender inequality in access to bank credits with a view to ascertaining the possibility of lop-sidedness in access to bank credit on gender basis and its implication(s) for the economy, management practice and the society.

\section{References}

Albert, M., Njanike, K. \& Mukucha, P. (2011). Gender Effects on Customer Satisfaction in Banking Industry: a case of commercial banks in Bindura, Zimbabwe. E3 Journal of Business Management and Economics, 2(1), 40-44.

Al-Somali, S., Gholami, R. \& Clegg, B. (2009). An investigation into the online banking acceptance in Saudi Arabia. Technovation, 29(2), $130-141$

Aregbeyen, 0. (2011). The determinants of bank selection choices by customers: Recent and extensive evidence from Nigeria. International Journal of Business and Social Science, 2(22), 276 - 288

Asikhia, 0. (2011). SMEs and Poverty alleviation in Nigeria: Marketing resources and capabilities implications. New England Journal of Entrepreneurship, 13(2), 57-70

Aterido, R., Beck, T. \& Iacovone, L. (2011). Gender and finance in Sub-Saharan Africa: Are women disadvantaged? World Bank Policy Research Paper 5571.

Awamleh, R. \& Fernandes, C. (2006). Impact of organizational justice in an expatriate work environment. Management Research News, 29(11), 701-712.

Bauer, K. \& Hein, S. E. (2006). The effect of heterogeneous risk on the early adoption of internet banking technologies. Journal of Banking and Finance, 30(6), 1713 - 1725.

Berger, S. C. \& Gensler, S. (2007). Online banking customers: Insights from Germany. Journal of Internet Banking and Commerce, 12(1), 1 - 6.

Blankson, C., Omar, O. E. \& Cheng, J. M. S. (2009). Retail bank selection in developed and developing countries: A cross-national study of students' bank-selection criteria. Thunderbird International Business Review, 51(2), 183-198.

Chiemeke, S. C., Evwiekpaefe, A. E. \& Chete, F. O. (2006). A study of price and quality in service operations. International Journal of Service Industry Management, 5(2), 23-34.

Cohen, D., Gan, C., Hwa, A. \& Chong, E. (2006). Customer satisfaction: A study of bank customer retention in New Zealand. Research Archive, Discussion Paper 03. Lincoln University.

Dusuki, A. W. \& Abdullah, N. I. (2007). Why do Malaysian customers patronize Islamic banks? International Journal of Bank Marketing, 25(3), 142-160.

Flynn, L. R. \& Goldsmith, R. E. (1993). Identifying innovators in consumer service markets. Service Industries Journal, 13(3), 97-109.

Fozia, M. (2013). A Comparative Study of Customer Perception toward e-banking services provided by selected private and public sector bank in India. International Journal of Scientific and Research Publications, 3(9), 71 - 84

Gan, C., Clemens, M., Limsomobunchai, V. \& Weng, A. (2006). A logit analysis of electronic banking in New Zealand. International Journal of Bank Marketing, 24(6), 360-383.

Hinson, R., Owusu-Frimpong, N. \& Dasah, J. (2009). Key motivations for bank patronage in Ghana. $\begin{array}{llll}\text { International Journal of Bank } & \text { 381-399. }\end{array}$ http://dx.doi.org/10.1108/02652320910979898

Howcroft, B., Hamilton, R. \& Hewer, P. (2002). Consumer attitude and the usage and adoption of home-based banking in the United Kingdom. International Journal of Bank Marketing, 20(3), 111 - 121

Karjaluoto, H., Mattila, M. \& Pento, T. (2002). Factors underlying attitude formation towards online banking in Finland. International Journal of Bank Marketing, 20(6), 261 - 272.

Kaynak, E., Kucukemiroglu, O. \& Odabasi, Y. (1991). Commercial Bank Selection in Turkey. International Journal of Bank Marketing, 9(4), 30 - 39.

Kolodinsky, J. M. \& Hilgert, M. A. (2004). The adoption of electronic banking technologies by US consumers. The International Journal of Bank Marketing, 22(4), 238 - 259. 
Levin, J. \& Milgrom, P. (2004). Introduction to Choice Theory. Curriculum Notes. (Online available http://www.milgrom.net/) Accessed 25 February 2015.

Lopez, J., Hart, L. K. \& Rampersad, A. (2007). Ethnicity and customer satisfaction in financial services sector. Managing Service Quality, 17(3), 259-274

Matila, A., Grandey, A. \& Fisk, G. (2003). The interplay of gender and affective tone in service encounter satisfaction. Journal of Service Research, 6(2), 136 - 143.

Maiyaki, A. A. (2011). Factors determining bank selection and preference in Nigerian retail banking. International Journal of Business Management, 6(1), 253 - 257.

Metawa, S. A. \& Almossawi, M. (1998). Banking behaviour of Islamic bank customers: perspectives and implications. International Journal of Bank Marketing, 16(7), 299-313.

Mokhlis, S., Salleh, H. S. \& Mat, N. H. N. (2011). What do young intellectuals look for in a bank? An empirical analysis of attribute importance in retail bank selection. Journal of Management Research, 3(2), 1-15.

Munusamy, J., DeRun, E. C., Chelliah, S. \& Annamalah, S. (2012). Adoption of retail internet banking: A study of demographic factors. Journal of Internet Banking and Commerce, 12(3), 1 - 14.

Muzividzi, D. K., Mbizi, R. \& Mukwazhe, T. (2013). An analysis of factors that influence internet banking adoption among intellectuals: A case of Chinhoyi University of technology. Interdisciplinary Journal of Contemporary Research in Business, 4(11), 350 -369

Narteh, B. \& Frimpong-Owusu, N. (2010). Customer knowledge and choice criteria in retail banking in Ghana. Paper presented at the 11th Annual Conference of the International Academy of African Business and Development [IAABD], University of Lagos, Nigeria. 544-550.

Nkamnebe, A. D. \& Ukenna, S. (2011). Factors Influencing Bank Choice among Undergraduates in Nigeria, Paper presented at the 12th Annual Conference of the International Academy of African Business and Development [IAABD], Athabasca University, Canada, 585-593.

Okoe, A. F., Osarenkhoe, A. \& Hinson, R. E. (2013). Using the analytical hierarchy process framework to study bank selection criteria of students in institute of professional studies Ghana. Journal of Management Strategy, 4(3), $27-38$.

Omar, O. E. (2007). Gender-Based Retail Bank Choice Decisions in Nigeria. Journal of Retail Marketing Management Research, 1(1), 20- 31

Rao, A. S. \& Sharma, R. K. (2010). Bank Selection Criteria Employed by MBA Students in Delhi: An Empirical Analysis. Journal of Business Studies Quarterly, 1(2), 56-69

Rashid, M. \& Hassan, M. K. (2009). Customer demographics affecting bank selection criteria, preference, and market segmentation: Study on domestic Islamic banks in Bangladesh. International Journal of Business and Management, 4(6), 131-146.

Sakkthivel, A. M. (2006). Impact of demographics on the consumption of different services online in India. Journal of Internet Banking \& Commerce, 11(3), 71-81.

Tootelian, D. H. \& Gaedeke, R. M. (1996). Targeting the college market for banking services. Journal of Professional Services Marketing, 14(2), 161-172.

Trocchia, P. J. \& Janda, S. (2000). A phenomenological investigation of Internet usage among older individuals. Journal of Consumer Marketing, 17(7), 605-616

Ukenna, S., Okoye, G., Ugwuomu, N. \& Monanu, O. (2012). Analysis of the influence of gender on the choice of bank in the south east Nigeria. International Journal of Business and Management, 7(3), 230- 241.

Wan, W. W. N., Luk, C. L. \& Chow, C. W. C. (2005). Customers adoption of banking channels in Hong Kong. International Journal of Bank Marketing, 23(3), 255-272

Wendy, W. N. W., Chung-Leung, L. \& Cheris, W. C. C. (2005). Customers' adoption of banking channels in Hong Kong. International Journal of Bank Marketing, 23(3), 255 - 272

Wilson, R. (1995). Marketing strategies for Islamic financial products. New Horizon, 39, 7-9

Zeithaml, V. A. \& Gilly, M. C. (1987). Characteristics affecting the acceptance of retailing technologies: A comparison of elderly and non-elderly consumers. Journal of Retailing, 63(1), 49-68 